\title{
MOVING QUEER VISIBILITIES INTO IDENTITY-SUSTAINING PRACTICES IN CYC: TOWARD QUEER(ED) FUTURES
}

\begin{abstract}
A Longoria
Abstract: This essay aims at connecting child and youth care (CYC) to U.S. teacher education, educator pathways, and schooling in the United States. Further, this essay addresses Wolfgang Vachon's call to push the boundaries of CYC, specifically in queering the field. I offer ways U.S. teacher education contexts and practices might be considered as guidance in supporting queer identities in CYC. I posit that there is a corporeal pedagogy that queer CYC practitioners enact that is effected beyond simple visibilities, and that they sustain their own identities and survival in CYC spaces through this practice. I also offer a testimonio of my practice as an out genderqueer, Chinese Mexican teacher educator who works in U.S. field-based teacher training and after-school CYC spaces. Further, I argue for critical engagement with curricula and field work in our training programs and make a call for training programs to support CYC practitioners in sustaining their queer identities. Finally, I argue for a need to continue to archive - and perhaps rescue - the practices and collective memories of queer CYC practitioners in order to advance a meaningful sustaining of queer identities in $\mathrm{CYC}$.
\end{abstract}

Keywords: identity-sustaining pedagogy, queer theory, child and youth care, teacher education

A Longoria (they/them) $\mathrm{PhD}$ is Assistant Professor of Secondary Education and Director of the Master in Teaching Program in the Woodring College of Education at Western Washington University, 516 High Street, MS 9089, Bellingham, WA 98225-9089.

Email: a.longoria@wwu.edu 
Recent debates in the United States about starting face-to-face schooling amid the COVID-19 crisis have brought to light a role for U.S. schooling that goes beyond instructional delivery and academics. The economic impacts to working families already affected by stay-at-home orders have underscored that U.S. schooling serves an implicit child and youth care (CYC) need. In this essay, I seek contemporary connections between CYC and U.S. teacher education, educator pathways, and schooling in the United States. Further, this essay addresses Vachon's (2020) call to push the boundaries of CYC, specifically with regard to queering the field. I offer insight into how U.S. teacher education contexts and practices might provide guidance in supporting queer identities in CYC settings. This essay also builds on notions of the teacher educator as role model (Lunenberg et al., 2006). Further, I argue for critical engagement with curricula and field work in our training programs and call for more ways to support CYC practitioners (CYCPs) in sustaining their queer identities. Through this essay, I hope to speak to teacher educators, CYC educators, CYCPs, and, most importantly, foster dialogue and build a nexus between these related fields of study and professional settings.

CYC and teaching are distinct, yet a comparative analysis can be drawn from examining the role that teachers in the United States, and CYCPs everywhere, engage with. There are enough analogous components to merit comparison through a queer(ed) lens ${ }^{1}$. The ways that the two professions intersect provide valuable insights into the ways youth might be best served, especially youth with marginalized identities. I draw upon my experiences as a genderqueer, Chinese Mexican, university-based, pre-tenure, assistant professor and teacher educator to explore the notion of pedagogical freedom as a practice of queer generosity (Rodriguez, 2012). A curious phenomenon in my teaching practice is that I feel most free to embody my queer identity when teaching. The agency I effect in constructing this pedagogical space - including virtual teaching during the global COVID-19 pandemic — gives me some reprieve from the world outside my courses, and my imaginary for a more just world is generated from this freedom. I argue that this act of queer generosity is a kind of embodied liberation modeled for my teacher education students and the subsequent pedagogies they will reify in their work with youth in the U.S. kindergarten to Grade $12(\mathrm{~K}-12)$ schooling system.

This essay also asks for whom this generosity - this corporeal pedagogy in teacher education - is constructed. In teaching future teachers, I explore how this generosity is constructed from a practice-based, explicitly preprofessional, context. Doing this work at a state university, not at a high output $\mathrm{R} 1^{2}$, and fulfilling the state-mandated call to educate teachers invokes a queer-class

\footnotetext{
${ }^{1}$ I use "queer(ed)" here to denote both the active process of queering CYC and teaching (queer), and its intended after-effects and transformative future (queered). As well, I playfully embrace the wordplay enacted with "ed" as shorthand for "education", which in the U.S. context encompasses teaching, learning, and youth issues, among other concerns of the field.

${ }^{2} \mathrm{R} 1$, or Research 1 universities, is a shorthand term used in the United States to refer to higher education institutions where faculty are expected to consistently produce published, peer-reviewed scholarship. This is often the
} 
analysis from a "poor queer studies" paradigm (Brim, 2020). This includes navigation of professional expectations, $\mathrm{K}-12$ school culture, youth culture, and the state-overseen preparation of teachers. Queer generosity, too, is a vehicle for sustaining my identities. In this agentive act, I enact an identity-sustaining pedagogy as an intersectional person of color (Rios \& Longoria, 2021).

What do I mean by queer? I use queer intentionally to be inclusive of multiple sexual and gender identities, including gender nonconforming, gender variant, and expansive identities (Green et al., 2020). It is admittedly inadequate, and some find an all-encompassing queer identity to be constricting. There is a wide variety of opinions about the best term to use in describing the queer community. K-12 schooling most commonly uses LGBT (lesbian, gay, bisexual, and transgender) or LGBTQ (to include those who identify as queer or those questioning their sexual orientation). Though I acknowledge that there are arguments against using "queer" as an allencompassing term, it remains the term most often used in queer popular culture, including activism (Mayo, 2014). Nevertheless, I acknowledge the wide variation of terms used by activist movements to self-identify (Jagose, 1996; Mayo, 2014).

A key idea explored in this essay is the notion of being out, the navigation of which queer teachers and CYCPs face in their schooling and professional contexts. "Out" means to be public about one's queer identities. Another way of referring to this is "visibility", for one is visible with one's queer identity or identitites by being out. Biegel (2010) suggested that in spite of the legal right to be out in schools, queer people must have the freedom to negotiate the terms for doing so. Thus, there is a kind of necessary agency and decision-making process queer teachers and CYCPs likely make in their classrooms and professional roles in navigating decisions about being out about their identities, negotiating various professional and contextual expectations, and determining safety in doing so.

Ghaziani and Brim (2019) articulated some problems that can arise in queer(ing) research methods, especially regarding quantification and the tensions between humanities and social science methodologies. Incorporating queer issues into teacher education poses its own disciplinary problems. Education, as a hybrid field, navigates tensions between its typical academic home in the social sciences, its influences from humanities scholarship, and its role as nexus between academic inquiry and praxis. Schooling and teacher education have been slow to incorporate queer(ed) contexts into practices and scholarship (Mayo, 2014). We queer teacher educators have had to enact a kind of queer generosity with the hope of encouraging an advent of our scholar-educator peers' awakening to queering the field in meaningful ways. Where then is our home to put down our queer(ed) roots in this field? I adapt Duncan-Andrade's (2010) writing on hope as a way to address this question: a critical hope tethered to a queer(ed) future. The way forward cannot be founded on an unexamined, empty hope, but rather one set on facilitating

paramount indicator used for judging whether such faculty are successful; it is often the primary criterion for attaining tenure and promotion. At non-R1 universitites, such publication requirements may be deemphasized in favor of teaching and service (working on university committees, etc.). 
liberation, or a more complex and critically informed hope. This essay seeks to imagine how we queer educators might work toward finding a home for ourselves in the field. To this end, I consider the question: In summoning the generosity to liberate others, how might we simultaneously liberate ourselves — as educators, trainers, and CYCPs — from oppression?

U.S. schooling today faces multiple continuing challenges. Teachers navigate tensions between teaching subject matter and attending to the social-emotional needs of students (Duncan-Andrade, 2009; Paris, 2012). The COVID-19 pandemic has growing implications for schooling and CYC in the United States (Charles \& Anderson-Nathe, 2020). In the first year of the pandemic there was a rapid shift in how schooling and school-based CYC services were delivered in the United States. The long-term effects of that shift have yet to be fully understood.

CYC spaces exist explicitly in U.S. schooling largely as after-school and summer spaces. Often these do not include teaching traditional academic content or serve, at best, to support such content in a supplemental way. CYC-like work can be seen, however, in the interstices of the many duties teachers juggle. Teachers volunteer to run after-school clubs, coordinate distribution of schools meals in their classrooms, and follow up with families about students' health and well-being amid their primary responsibilities in instruction. I argue that queering CYC and creating a stronger queer lens on teacher education might allow us to understand CYC better, especially if these take place within a reciprocal process that benefits both practice and theory. Vachon (2020) rightly pointed out disciplinary tension in defining CYC; I extend this argument by suggesting that teacher education in the U.S. context might offer important insights for CYC and CYCPs, especially in queering practice.

Early 21 st century reforms to teacher practice and teacher education brought a marked shift to the profession. Policies like No Child Left Behind (2002) brought an academic focus to teacher training and attempted to increase learning accountability through high-stakes testing. The reforms also created a strict and complicated bureaucratic system. To become certified, teachers had to meet stringent requirements including extensive coursework and prequalifying exams. While the focus on academics and achievement wrought through these reforms shifted attention away from the CYC dimension of teaching, the need for CYC teacher practices, including those that attend to social-emotional needs, care, and justice work, did not diminish.

I maintain that these extensive reforms institutionalized a comprehensive, university-based training program under which teacher education programs can serve as a venue for disseminating adaptations to teacher training. Especially with regard to social justice and liberatory approaches to education, this comprehensive system holds the potential to reach teachers in training and encourage such approaches as foundational to their emerging professional practice - hopefully, one that will be sustained throughout their careers. In the absence of this system, it is likely that school reform would lack an adequate apparatus to effect comprehensive change. 
Taken together, U.S. schooling and teacher education are arguably the best analogy for understanding CYC and CYCP education in context. While U.S. education scholarship has a substantial literature base replete with considerations for teacher education and practice, it has not adequately taken up CYC perspectives nor readily considered its ample connections to CYC scholarship. Nevertheless, teacher education has a strong foundation — particularly in theoretical and qualitative literature - to help envision supporting diverse identities within its systems. While literature seeking to queer teacher education and teacher practice is still emerging, its more recent output might provide important insights for CYC studies.

I wholeheartedly agree with Gharabaghi and Anderson-Nathe (2011) that a global approach to CYC practice is limited by our own perspectives and practices while simultaneously being boosted by our efforts to overcome these limitations and by our openness to other perspectives and CYC settings. I offer that U.S.-based teacher education settings - my own current setting — might be useful in understanding how we could collectively continue to queer CYC work and spaces. This is not to impose some U.S.-centric analysis, or worse, a U.S. exceptionalism, upon comparable CYC scholarship or practice, but rather to suggest that U.S. teacher education, and, more broadly, the field of education in the U.S., has made advances to queering its own contexts that might offer support for global CYC spaces (Kumashiro, 2002; McReady, 2010; Pascoe, 2012). As I argue here, CYCP and teacher queer identities are imperative to the work of queering CYC.

\section{Sustaining Queer Identities}

It is likely that there have always been queer teachers in $\mathrm{K}-12$ schools in the United States. While there has been a complex string of recent wins in legal and policy protections for queer identities, within schooling the legal visibilities - freedom from termination of employment or other repercussions - have been relatively recent developments (Will, 2020). Controversy around the rights of queer people persists, especially for gender-variant identities, such as trans and nonbinary ${ }^{3}$ identities. For intersectional identities - most saliently queer teachers of color — the schooling landscape represents multiple professional and pedagogical contexts to navigate for identity survival.

Schooling and CYC spaces are sites of binary gender sorting — that is, they remain sites of compulsory gendering. This process might be as subtle as teachers or CYCPs defaulting to having students line up for recess by gender - boys and girls. Other more insidious ways this process plays out can be seen in the ways youth police each other's gender performance in what Pascoe (2012) called the "fag discourse".

In the face of this sorting, how might teachers and CYCPs transgress the rules and conditions of spaces that actively seek to silence or invisibilize queer people, or otherwise to compel — both implicitly and explicitly — heteronormative and cisnormative norms? Queer educators and CYCPs

\footnotetext{
${ }^{3}$ Stryker (2017) describes nonbinary people as "people who do not conform to binary notions of the alignment of sex, gender, gender identity, gender role, gender expression, or gender presentation” (p. 24).
} 
might sustain their queer identities by actively transgressing such norms and insisting on asserting their identities in these spaces. Possible ways of transgressing norms include insisting on one's pronouns in spite of their lack of use in a professional space, and wearing professional attire that matches one's gender identity, not one's perceived or compulsory gender. Further, these identitysustaining practices should be rigorous and professional, and, most importantly, would provide beneficial modeling for the children and youth that queer professionals serve.

Rios and Longoria (2021) argued that Black teachers, Indigenous teachers, and other teachers of color might actively sustain their identities in their teaching practice by resisting identity silence - the identity-neutral approaches implicit in professional standards and schooling practices that seek to normalize White dominance ${ }^{4}$. Identity-sustaining pedagogy is rooted in multicultural education, a field that seeks to envision schooling and education that serves a pluralistic population of diverse youth and communities while also envisioning and working toward necessary reforms (Banks, 2004). Above all, this essay offers a queer(ed) application of Rios and Longoria's (2021) notion of identity-sustaining pedagogies. I argue that queer CYCPs might engage in sustaining their own identities — and survival in CYC spaces — by engaging in the identity-sustaining pedagogy framework that includes resisting identity silence, actively including identity in CYC practice, normalizing pushback, and empowering other identities.

Despite scholarship not having directly engaged in queer teacher practices toward identitysustaining pedagogies, research and scholarship have sought to address similar themes and have provided important insights, mostly at the conceptual level. Rodriguez (2012) suggested that queer embodiments - the ways that queer bodies exist and function within a given space — enact a kind of pedagogy that inspires other queer students to imagine their own embodiments. He also framed these pedagogies as a type of generosity enacted through these embodiments. Rofes (2000) supported a similar point through his retrospective analysis of the impacts his queer identity had on students. He surveyed his former students (by then adults) to ascertain whether his being openly gay had any lasting effects on their learning experiences. Rofes concluded that teachers may play a central role in the moral development of youth and provide students with a model of how an adult can navigate a marginalized or controversial identity.

Rasmussen (2004) reviewed relevant, extant scholarship on queer teacher identity, especially empirical studies that examined the various parameters teachers navigate in determining visibility for queer identities. She contended that queer teachers construct their queer identities based on individual and contextual factors, such as time, space, and schooling site. She further argued that as queer teachers navigate visibility their identities are "constructed via moral, political, and pedagogical considerations related to the production of sexual identities" (p. 149). Nevertheless, it is clear that scholarship has given too little attention to queer teacher practice, especially

\footnotetext{
${ }^{4}$ Some examples of identity-neutral practices in the U.S. context include: using English or anglicized versions of names that are different from those used in one's ethnic group, professional hairstyle expecations that do not account for different hair textures, and discouraging translanguaging or bilingual practices. For additional information, see Rios and Longoria, 2021.
} 
scholarship that tests and builds on these conceptual assertions. Ghaziani and Brim (2019) reinforced this point:

Queer pedagogies can orient us, even in the midst of the powerfully disorienting focus of the neoliberal academic marketplace, by allowing us to think critically and expansively about what kind of teacher-scholars we want to be - with whom, for whom, and where. (p. 22)

While simultaneously lamenting the excessive theorizing that saturates queer studies scholarship, the authors suggested that advancing the field must include an agenda that examines how queer theory is enacted through pedagogical applications - and then acts upon what this work reveals.

Intersectionality, with its complex interplay of identities, is also an important concept in examining sustaining identities for queer teachers and CYCPs. Originally coined by Crenshaw (1991), the term has been popularly used as a buzzword simply indicating multiple identities. More pressing is the imperative that the term should be used in the service of aims that entail social change (Collins, 2019). Muñoz (1999) extended Crenshaw's (1991) conception to include queer identity. He suggested that "disidentifications" (p. 8) - ways in which one can contradictorily and paradoxically both identify with and push back on identities — can help explain ways queer minoritized groups respond to cultural dominance. These disidentifications are extensions of intersectional experiences that amplify the contexts that must be considered in interactions with cultural dominance. For racialized CYCPs, disidentifications can be seen as a queer of color version of Crenshaw's intersectionality.

\section{A Corporeal Pedagogy}

Queer identity-sustaining practices are necessarily corporeal pedagogies. This means that queer educators and CYCPs who enact these pedagogies do so through their very bodies existing within a schooling or CYC site. As they insist on visibility and openly sharing their identities through the process of being out and other actions, they necessarily push the boundaries of heteronormative and cisnormative expectations. To be clear, this visibility itself teaches others to challenge and eventually to adapt through either cognitive dissonance or critical thinking processes. It is hoped that changes to normative expectations in the schooling or the CYC site would result. Corporeal pedagogies, as I argue here, are not involuntary, passive acts. They are not enacted simply from existing within a space. Rather, there is a body-bound dimension to corporeal pedagogies - one enacted regardless of the actions of the educator or CYCP seeking to transgress norms - that stems from this conscious visibility. Admittedly, there is an ontological potential that is realized in identity-sustaining practices; these should ultimately be seen as secondary to intentional acts to preserve one's dignity, humanity, survival, and generosity in teaching or serving 
"to and through"5 the preservation of one's queer identities. It is a decided act of survival for queer teachers and CYCPs to sustain their identities through their professional practice.

One way to teach others about our experiences is to enact testimonios, or testimonies. The testimonio is a practice rooted in critical race theory that aims to empower stories from people with nondominant identities to speak back to beliefs present in the dominant culture (Cruz, 2012; Peréz Huber, 2009). In other words, in testimonios we teach others about the world through the experiences of our bodies. Testimonios are intended to help readers and listeners to our stories to build solidarity with each other toward some common changes necessary to our collective work (Cruz, 2012).

My testimonio speaks to my experiences in an innovative CYC-teacher education hybrid space, working in a teacher pathways program with an in situ teacher education practice. I insist on holding my teacher education courses in school settings. I believe it is important for teacher candidates - those training to be teachers - to have direct service with youth. As they navigate the nuances of practices, these teacher candidates have opportunities for enacting real praxis for course readings and themes.

I have also had opportunities to hold in situ courses for teacher pathways students. These are courses designed for students considering a professional career in education, typically as a teacher or youth worker. My university colleagues and I call this pathways course and its associated program Family and Community Engaged Teaching, or FACET (Larson et al., 2019). A key feature in our courses is that faculty members work alongside students in enacting direct service with youth. We as faculty are thus able to introduce our student apprentices to critical and humanizing praxis, and can facilitate reflections on direct service, especially to make connections between course readings and themes, and to troubleshoot problems arising in practice.

Under FACET, I work with apprentice undergraduate CYC students who volunteer in an afterschool program with middle school youth. Admittedly, the disciplinary and definitional boundaries between CYC and teacher education, especially in the U.S. context, are unclear. This work is only a beginning toward bridging the two, yet our FACET work has clearly revealed that we need more CYC in teacher preparation. For teacher education, this is an innovative space: while acquiring first-hand experience working with youth, our students can begin to discern their potential path toward applying for and studying in our teacher education programs toward professional licensure. For this pathway program, we try to center CYC work and experiences. We believe - in disagreement with the No Child Left Behind reforms - that this approach to preparing teachers is far more sustainable and facilitates a more just practice than alternative approaches with a greater

\footnotetext{
5I extend Gay's writing on culturally responsive teaching here to support my argument about queer teacher and CYCP practice. Gay (2018) wrote that culturally responsive teaching seeks to teach "to and through [students'] personal and cultural strengths" in order to boost their achievement and success in schooling (p. 32). In their framework for identity-sustaining pedagogy, Rios and Longoria (2021) extended ideas about culturally responsive teaching to apply to teacher of color practice.
} 
focus on academics. Further, I contend that teacher education programs sometimes lose sight of the importance of preparing teachers for roles that necessarily involve working with children and youth professionally. Building this orientation - a type of realistic, practical, preprofessional preparation — is essential to liberatory work.

The work my colleagues and I do facilitates reflective practice, which I believe helps to cultivate the kinds of critical thinking about practice that are necessary for making space for diverse identities and the liberation needed to sustain them within CYC and schooling spaces. In the most recent pre-pandemic offering for this coursework, a colleague and I held our FACET class in a local middle school afterschool program in a school that serves the most racially and economically diverse population for its age group in the district. As far as I know, it is as yet the only school in the district that allows youth to self-identify as gender variant in official recordkeeping.

My colleague and I cotaught a 2.5 hour course that included a 45 minute pre-service class, one hour of direct service with youth, dinner with the youth, and a 20- to 30-minute debrief after the direct service. In this work, we attempted to center youth knowledge and learn about the community. This included community mapping, frequent informal interview projects with youth, research gathering on community demographic data and history, and, often, youth joining our debrief spaces for further insight and member checks on our processing of practice and praxis. This orientation to CYC ultimately facilitated identity-sustaining practice and queering work with youth. Our pathways students were constantly asked to reflect on how their own identities inform their practice, how student identities were at play in service, and how to critically engage with changes to practice in serving youth and communities. We believe that when students are apprenticed into humanistic work, identities become more central and germane to the work than the more academic goals of teaching, although those are still important.

Throughout all of this work, I, as a university professor, find visibility and my own enactment of identity-sustaining pedagogy to be central to how I mentor CYC apprentices. In my testimonio of practice, I offer my experience as a genderqueer person working with youth and their community in a field setting. Though this testimonio is necessarily a personal statement, please note that the work and setting that I detail in this essay is part of a larger collective process in working in this CYC space.

\section{Longoria's Testimonio}

\section{Introduction}

I find much validation in the "subcultural" connotation that genderqueer evokes, especially in being a genderqueer person of color in a larger, national queer community that so often feels dominated and defined by White queerness (Stryker, 2017, p. 24). Following the U.S. 2016 election, I made the decision to be out about my genderqueer identity. I first transitioned to using my preferred name, Longoria, rather than my birth name. I later asked people to use they/them 
pronouns to further honor my genderqueer identity. Throughout this process, I have navigated a kind of aesthetic - how to present my gender identity through attire and cosmetics - that fits within the professional settings in which I operate.

Working in university, school, and CYC settings means that I navigate spaces that have received queer identities in various ways. In university settings, as a university professor, my transition and outness were more easily effected. In schooling and CYC settings, I find myself more cautious, especially when I do not know enough about the space. This sometimes translates to concern for my personal safety, but more often manifests as caution.

I do not mean to deny the complexity and difficulty of being visible and enacting identitysustaining practices. I offer a testimonio on these experiences here.

\section{The Testimonio}

I recount my thinking from my most recent work in a CYC afterschool setting. Walking through the parking lot before and after service with youth. The gaze of families and not knowing how they will perceive me. Will today be the day that I will be questioned? Should I push other CYCPs that I do not have a professional relationship with to insist on my pronouns? So many thoughts run through my head as I enter into CYC and schooling spaces: I worry that my nail polish, my typical turquoise blue, is too bright. I worry that parents will question my qualifications or reasons for being in the afterschool space. I worry that my braid is too unkempt and this will reflect poorly on queer educators. And then there is the business of my name badge. It is unusual - a type of queering - in that it shows, rather than a typical binomial name, my preferred name: Longoria.

Related acts where my difference comes up are found even in the act of signing in at the school's front office. Though a necessary step to ensure school safety and follow its practices, I have been challenged to sustain my queer identity in these spaces. My mononym is sometimes not accepted as sufficient to use for sign in. Some staff have challenged my sign-in name and required that I use my full legal name. Moreover, some staff that do not know my gender identity have called me "sir" or referred to me using masculine pronouns. More recently, I have started to use a pin that reads "they/them" to signal to others my pronouns and gender identity.

Although these types of transgression might seem trivial, they effect a sustaining of my queer identity and my self-determination. Yet, my active queering of norms is not spectacle - my name

badge resists patriarchal binomial standards by simply rendering my mononym while still serving its necessary purpose in signaling to others in the space that I have been vetted for school safety. Sustaining our identities in CYC spaces is necessary and pragmatic, but meets with ongoing resistance. 
International Journal of Child, Youth and Family Studies (2021) 12(3/4): 152-169

\section{An Act of Generosity and Futurity}

In their framework for identity-sustaining pedagogies, Rios and Longoria (2021) suggested that one needs to "normalize pushback" - to expect resistance and use it as a positive, critical tool. My testimonio illustrates that identity-sustaining pedagogy is not built upon passive acts: we effectively teach others about our identities by means of a process enacted through our very bodies. There will be resistance to our intentional sustaining of our identities. Yet, this reciprocal process not only effects an active queering of the spaces we exist and work within, but also serves to empower other identities.

While working in field-based settings, there are times when I must take the time to insist that a new colleague try using my pronouns, or must stop what I am doing to answer a question from a curious teenager. This, at times, demands that I enact patience and generosity in spite of any frustrations. Thus, identity-sustaining pedagogies are acts of queer generosity (Rodriguez, 2012). This is not some docile or passive generosity; rather, it is one that has an eye toward the future and for liberation. My insistence on my pronouns is also an act of ensuring our collective queer futurity - a move toward the goal of collective liberation (Muñoz, 1999). This work encompasses a collective commitment toward a future that liberates all children and youth — and their communities — from heteronormative and cisnormative oppression.

Returning to the concept of intersectionality (Collins, 2019), my multiple identities are a kind corporeal theory realized. As a mixed-race Chinese Mexican American queer person, the intersections of these identities bear on my work as a teacher educator. Being a person of color (POC) and queer POC is foundational to my work. Because I am often the first queer POC that youth, my teacher education students, fellow teachers, and CYC colleagues have worked with, I often navigate being a "first-and-only" for them. Beyond the novelties of my being a "first" for people, I wrestle with the question: How do I not compromise or silence my identities? For example, my queer identity cannot be isolated from my racialized identities as a Chinese Mexican person. I struggle to resist hiding my identities amidst cultural difference. Further, queerness — at least in the U.S. context — is particularly intertwined with Whiteness. To consider queer identities in simple isolation, outside the context of intersectional identities, is to invisibilize the complex work queer teachers and CYCPs navigate in sustaining their identities. This is even more important for POC teachers and CYCPs working in schools and CYC settings.

Some researchers have suggested that navigating notions of adulthood and expected adult roles in youth and school settings can add to the challenges faced by queer researchers (Pascoe, 2012; Slovin, 2020). In many school and youth work settings, adults are effectively categorized according to a simple binary: those with relevance (and authority) and those of little consequence (and with little to no authority). The latter category is often applied to guests and volunteers in such spaces. I suggest that my work in such settings relies on my being seen as an adult with relevance. My work as a first-and-only, I believe, helps change conditions for other queer and POC CYCPs and educators in the space. Given my unique, intersectional identities within such spaces, 
there is a kind of (role) modeling that I navigate. This suggests that a multilevel practice of identitysustaining pedagogies might help change conditions for all queer people within a setting, even if such changes are enacted for a future realized long after we have completed our own work within a space.

\section{Not Without Costs}

There is a danger to enacting visibility. It is important to acknowledge that queer teachers and CYCPs must navigate risks in enacting their identity-sustaining pedagogy. Some communities are not supportive. I do not mean to romanticize visibility or corporeal pedagogies, because doing so comes at a potential cost to safety. Queer teachers and CYCPs will need to be mindful of their own professional and community contexts to ensure that their own outness and visibility can be effected safely. When it is safe to do so, we as queer educators and CYCPs teach our colleagues, youth, and families how to ensure our survival when we purposely sustain our identities through our professional work.

Pennell (2016) offered a counter-framework to traditional notions of cultural capital that gives schooling professionals a way to highlight queer people's strengths, not their deficits, in what she calls "queer cultural capital". As queer teachers and CYCPs enact visibility and actively work to sustain their identities in their professional settings, they build queer cultural capital. Perhaps the accumulation of such capital within the systems in which we work might help to create more capacity for liberation of other minoritized identities. Queer teachers and CYCPs hold queer cultural capital and, more importantly, sustain their queer cultural capital through identitysustaining practice. Yet this sometimes comes at risk to personal safety.

Slovin (2020) wrote about their experiences navigating working with youth and queer identity when conducting ethnographic research in a high school in Western Canada as a non-binary researcher. Key to their argument that “a person's adherence to cisheteronormative logics is an integral aspect of being recognized as an adult" (p. 225) is their recognition of the nuanced differences between how youth and adult professionals in the school setting perceive who is and who is not an adult within the space. This has bearing on the contexts queer teachers and CYCPs navigate and might be important in considering the effects of visibility within a space.

With a particular eye toward aesthetics, Alvarez (2016) wrote "Finding Sequins in the Rubble", which seeks to theorize the ways Latinx queer and trans people in Los Angeles "make sense of their lives and engage in an ongoing process of self-fashioning that involves aesthetic and affective strategies and fashion and style negotiations" (pp. 624-625). Here, I extend Alvarez's concept for theorizing the ways CYCPs and teachers navigate and negotiate their own queer identities. Alvarez reminds us that aesthetics are not trivial and are often a site of queer survivance. How then might this play out in CYC and schooling spaces? It is not insignificant that queer CYCPs and teachers enact their queer identities through aesthetics. Perhaps for the dominant culture, one's sartorial choices must adhere to explicit norms for professionalism and gender, and implicit norms for respectability. Queer people transgress these norms for visibility or outness, at times for political 
reasons and at other times for survival. These transgressions are important for pushing back against the potentially restrictive and policed norms present in our spaces (Vachon, 2013, 2020). For youth, such aesthetic representations - a kind of corporeal pedagogy — present an ontological model, or, more affectively, a necessary hope that a queer life can be lived visibly and with purpose.

Modeling gender possibilities is important too. Keenan (2017) argued that there is a powerful modeling trans teachers can effect in this work. He maintained that teacher educators hold power in helping students rethink and reimagine gender variance through a process he called "unscripting". There are, however, limitations to this work. Keenan related that there is deeper societal work to unscripting gender. Yet, in working with youth, Keenan argued that allowing youth to articulate the terms of their own sensemaking about gender, and, more importantly, encouraging play and experimentation in doing so, might make more space for diverse gender identities and the conditions to support them.

CYCPs must enact corporeal pedagogies that are effected beyond simple visibilities: they must teach through their very existence - especially as out practitioners - in CYC spaces. How then might they sustain their identities through practices and direct service with children and youth? Further, how might training programs work toward empowering practitioners to sustain their identities through praxis? This extends Keenan's (2017) notion of unscripting. In what ways can teachers, teacher educators, CYC educators, and CYCPs work toward conditions that allow for unscripting?

In queering CYC spaces, there is an ongoing need to resist homonormativity. Homonormativity refers to a limiting and restrictive sameness or singularity in queer identity (McCann \& Monaghan, 2020). It is important to keep in mind that the term "queer" comprises myriad identities. By one simple definition, "queer" refers to that which is not normal. Yet, queerness itself should defy definition (Jagose, 1996). There is a danger in normalizing singular, universal queer identities (i.e., stereotypes). While we might use "queer" as a kind of umbrella term in practical settings, we still seek to ensure that CYCPs make space for diverse queer identities. It might be too easy to call this intersectionality, for that term has euphemistic connotations. In many ways, "intersectionality" has been watered down by popular applications of the term. Queer teachers and CYCPs have much potential to help further the development of expansive ways to envision a diverse queer community. It does not seem fanciful to hope that sustained activity of this type could produce meaningful change.

Obergefell v. Hodges (2015) is the landmark Supreme Court decision that legally allowed same-sex marriage in the United States. There is a danger that, in this post-Obergefell society, some might erroneously view the decision as having won queer rights for all, but that would fail to acknowledge the legal precarity of same-sex marriage and the ongoing lack of gender protections for CYCPs and educators. Post-Obergefell society thinking also invisibilizes nonhomonormative queer identities. In truth, queer legal protections remain precarious. Legal wins 
for queer rights triggered a conservative backlash that, under the Trump administration, led to many trans protections being dissolved (Fadulu, 2019). Since President Biden was elected in 2021, there has been a renewed increase in anti-trans legislation at the state level and is focused on preventing trans youth from accessing healthcare that affirms their gender identities and other legislation attempting to limit trans youth participation in sports (National Public Radio, 2021). For these reasons, it is important that CYC contexts remain spaces that protect and affirm queer identities, fostering self-determination and offering safety regardless of the political and legal landscape. Although policies must be followed and laws must be obeyed, there remains the necessity for CYC practices to stay true to queer-supportive praxis regardless of political forces outside explicit CYC contexts.

In our global pandemic world, amidst the turmoil of sudden and ongoing change to society, schooling, and CYC spaces, challenges to sustaining identities have emerged and may persist. We must continue to document, study, and find ways to help queer CYCPs sustain their identities in virtual settings. Because screen names, cameras, lighting, and other technology help users to alter their appearance, gathering remotely may come with a benefit: queer CYCPs and educators can curate their appearance to more accurately reflect their queer identities - to more effectively sustain those identities. While some guidance might be gained from previous research on virtual spaces (Kidd, 2017) — especially with regard to providing a support for queer identities — the changing landscape offers more questions than answers.

\section{Concluding Thoughts}

Professions that work with youth — both CYC and the teaching profession - will necessarily evolve to serve the needs of queer youth, especially as more queer people enact visibility and as laws and policies change to better serve their humanity and dignity. With recent legal wins over the last 10 years for some queer people in the United States, there is a danger of settling into postObergefell society paradigms that might inhibit critical reforms toward meaningful queering of schooling and CYC spaces. Instead, our work requires that we continue to archive - and perhaps rescue - the practices and collective memories of queer CYCPs in order to advance a meaningful sustaining of queer identities in CYC specifically. It is particularly important for queer people of color to rescue their own sensemaking and narratives (Alvarez, 2016). I implore teachers and teacher educators, CYC educators and researchers, and CYCPs to document and examine their practices as they relate to queering CYC and youth work. The production of knowledge is imperative to ensure a queered future in $\mathrm{CYC}$, especially for training programs. Amid the global pandemic, still raging as this article goes to press in the late summer of 2021, it becomes even more important to archive the work that has been done and to take stock of what work has yet to be done, rather than let this moment of rapid change to our systems dictate priorities for reform. This work may also include engaging both university and privately held archives to record oral histories, especially of queer CYCP experiences. Admittedly, this call is U.S.-centered, but it is 
hoped its applications will inspire corporeal pedagogies to be archived and honored in their contexts across borders.

Insisting on our identities is liberatory. As queer teachers and CYCPs make the conscious choice to sustain their identities, their actions will undoubtedly facilitate further positive change for all queer people within their professional settings. By choosing to sustain their identities, they work toward their own survival and pave the way for other queer people to do so within the spaces they share. This liberation is not without its costs: all queer people within schooling and CYC spaces must consider their personal safety, the safety of other queer people, and the full ramifications of visibility. It will be important for allies in this work to help ensure that conditions in such spaces will help, rather than hinder, queer teachers and CYCPs to sustain their identities. Training programs will need to critically examine and revise their curricula and practices in order to help facilitate this work. While the long-term impacts of the global pandemic cannot yet be fully understood, this era promises, at minimum, a lasting change to schooling and CYC. What might it mean for us as teachers and CYCPs to seize this opportunity to purposefully remake practice for queer(ed) empowerment? What might it mean for us to intentionally center the sustaining and survival of queer(ed) identities in our schools and CYC settings? The answers to these questions — informed by contexts of the respective educative and CYC spaces - encompass a necessary collective futurity. 
International Journal of Child, Youth and Family Studies (2021) 12(3/4): 152-169

\section{References}

Alvarez, E. F., Jr. (2016). Finding sequins in the rubble: Stitching together an archive of trans Latina Los Angeles. Transgender Studies Quarterly, 3 (3-4),618-627. doi:10.1215/23289252$\underline{3545299}$

Banks, J. A. (2004). Multicultural education: Historical development, dimensions, and practice. In J. A. Banks \& C. A. McGee Banks (Eds.), Handbook of research on multicultural education (2nd ed., pp. 3-29). Jossey-Bass.

Biegel, S. (2010). The right to be out: Sexual orientation and gender identity in America's public schools. University of Minnesota Press.

Brim, M. (2020). Poor queer studies: Confronting elitism in the university. Duke University Press.

Charles, G., \& Anderson-Nathe, B. (2020). Uncertainty in the time of coronavirus. Child \& Youth Services, 41(1), 1-2. doi:10.1080/0145935X.2020.1753377

Collins, P. H. (2019). Intersectionality as critical social theory. Duke University Press.

Crenshaw, K. (1991). Mapping the margins: Intersectionality, identity politics, and violence against women of color. Stanford Law Review, 43, 1241-1299.

Cruz, C. (2012). Making curriculum from scratch: Testimonio in an urban classroom. Equity \& Excellence in Education, 45(3), 460-471. doi:10.1080/10665684.2012.698185

Duncan-Andrade, J. (2009). Note to educators: Hope required when growing roses in concrete. Harvard Educational Review, 79(2), 181-194. doi:10.17763/haer.79.2.nu3436017730384w

Fadulu, L. (2019). Trump's rollback of transgender rights extends through entire government. The New York Times. https://www.nytimes.com/2019/12/06/us/politics/trump-transgenderrights.html

Gay, G. (2018). Culturally responsive teaching: Theory, research, and practice (3rd ed.). Teachers College Press.

Gharabaghi, K., \& Anderson-Nathe, B. (2011). Editorial: Living, working, and writing about global children and youth. Child \& Youth Services, 32(1), 214-218.

doi:10.1080/0145935X.2011.566148

Ghaziani, A., \& Brim, M. (2019). Imagining queer methods. New York University Press.

Green, J., Hoskin, R. A., Mayo, C., \& Miller, sj. (2020). Navigating trans*+ and complex gender identities. Bloomsbury. 
International Journal of Child, Youth and Family Studies (2021) 12(3/4): 152-169

Jagose, A. (1996). Queer theory: An introduction. New York University Press.

Keenan, H. B. (2017). Unscripting curriculum: Toward a critical trans pedagogy. Harvard Educational Review, 87(4), 538-556. doi:10.17763/1943-5045-87.4.538

Kidd, D. (2017). Social media freaks: Digital identity in the network society. Westview.

Kumashiro, K. (2002). Troubling education: Queer activism and antioppressive pedagogy. Routledge.

Larson, B., Baker-Sennet, J., Chu, M., Korsmo, J., Longoria, A., \& Velez, V. (2019, April 5-9). Family and community engaged teaching: A systems approach to pre-service teacher preparation [Paper presentation]. American Educational Research Association (AERA) Annual Meeting, Toronto, Ontario.

Lunenberg, M., Korthagen, F., \& Swennen, A. (2007). The teacher educator as a role model. Teaching and Teacher Education, 23(5), 586-601. doi:10.1016/j.tate.2006.11.001

Mayo, C. (2014). LGBTQ youth and education: Policies and practices. Teachers College Press.

McCann, H., \& Monaghan, W. (2020). Queer theory now: From foundations to futures. Red Globe Press.

McCready, L. T. (2010). Making space for diverse masculinities: Difference, intersectionality, and engagement in an urban high school. Peter Lang.

Muñoz, J. E. (1999). Disidentifications: Queers of color and the performance of politics. University of Minnesota Press.

National Public Radio. (2021, March 15). What's driving the spate of anti-transgender state legislation? https://www.npr.org/2021/03/15/977535344/whats-driving-the-spate-of-anti$\underline{\text { transgender-state-legislation }}$

No Child Left Behind (NCLB) Act of 2001, Pub. L. No. 107-110, § 101, Stat. 1425 (2002). https://files.eric.ed.gov/fulltext/ED556108.pdf

Obergefell v. Hodges, 576 U.S.___(2015). https://www.supremecourt.gov/opinions/14pdf/14$\underline{556 \quad 3204 . p d f}$

Paris, D. (2012). Culturally sustaining pedagogy : A needed change in stance, terminology, and practice. Educational Researcher, 41(3), 93-97. doi:10.3102/0013189x12441244

Pascoe, C. J. (2012). Dude, you're a fag: Masculinity and sexuality in high school (2nd ed.). University of California Press. 
International Journal of Child, Youth and Family Studies (2021) 12(3/4): 152-169

Peréz Huber, L. (2009). Disrupting apartheid of knowledge: Testimonio as methodology in Latina/o critical race research in education. International Journal of Qualitative Studies in Education, 22(6), 639-654. doi:10.1080/09518390903333863

Pennell, S. M. (2016). Queer cultural capital: Implications for education. Race Ethnicity and Education, 19(2), 324-338. doi:10.1080/13613324.2015.1013462

Rasmussen, M. L. (2004). The problem of coming out. Theory into Practice, 43(2), 144-150. doi:10.1207/s15430421tip4302 8

Rios, F. A., \& Longoria, A. (2021). Creating a home in schools: Sustaining identities for Black, Indigenous, and teachers of color. Teachers College Press.

Rodriguez, N. (2012). Queer imaginative bodies and the politics and pedagogy of trans generosity: The case of Gender Rebel. In J. C. Landreau and N. M. Rodriguez (Eds.), Queer masculinities: A critical reader in education (pp. 267-288). Springer. doi:10.1007/978-94$\underline{007-2552-2 \quad 16}$

Rofes, E. (2000). Young adult reflections on having an openly gay teacher during early adolescence. Education and Urban Society, 32(3), 399-412. doi:10.1177/0013124500323008

Slovin, L. (2020). What grade are you in? On being a non-binary researcher. Curriculum Inquiry, 50(3), 225-241. doi:10.1080/03626784.2020.1754730

Stryker, S. (2017). Transgender history: The roots of today's revolution (2nd ed.). Seal Press.

Vachon, W. (2013). Do not enter: What are the risks of gatekeeping child and youth care? Child \& Youth Services, 34(2), 156-171. doi:10.1080/0145935X.2013.785888

Vachon, W. (2020). Queering child and youth care. International Journal of Child, Youth and Family Studies, 11(2), 61-81. doi:10.18357/ijcyfs112202019519

Will, M. (2020, June 15). LGBTQ teachers celebrate Supreme Court ruling on workplace protections. Edweek. https://www.edweek.org/teaching-learning/lgbtq-teachers-celebratesupreme-court-ruling-on-workplace-protections/2020/06 